Chapter 9

\title{
A Review on the Assessment of the Potential Adverse Health Impacts of Carbamate Pesticides
}

\author{
Elsa Dias, Fernando Garcia e Costa, \\ Simone Morais and Maria de Lourdes Pereira \\ Additional information is available at the end of the chapter \\ http://dx.doi.org/10.5772/59613
}

\section{Introduction}

Carbamates are an important class of pesticides used worldwide in public health, among rural and urban settings. Indeed, due to their mode of action and effectiveness, the application of these compounds is one of the best options presently offered for pest control in modern agriculture. They are also used for gardening, and as therapeutic pharmaceuticals for veterinary medicine. Carbamates have been also used in medicine for myasthenia gravis, an autoimmune disease which affects the postsynaptic element of the neuromuscular junction, and as pre-exposure protection in military settings from chemical warfare nerve agents such as Sarin and Tabun. For example carbamates such as physostigmine, and pyridostigmine have been listed as human drugs. However, current environmental concerns of the deleterious health impacts of carbamate pesticides have been increasing. Humans and other non-target species are exposed to residues of these cholinesterase-inhibiting chemicals via nutritional sources (legumes, fruits, contaminated meat, and dairy products), water and/or through environmental/occupational settings due to inappropriate handling. As other pollutants, carbamates may induce deleterious effects on both biotic (micro and macro fauna and flora) and abiotic systems. The adverse effects of several carbamate pesticides include renal, hepatic, neurological, reproductive, immune, and metabolic functions in both humans and animals. Furthermore, some of them are classified as endocrine disrupting chemicals [1], and regarded as priority pollutants by the United States Environmental Protection Agency (US EPA) [2].

In this chapter a brief overview of the current knowledge on the carbamates' mode of action and toxicological aspects is presented. The role of in vivo studies (histological and hematological approaches), epidemiology and interdisciplinary research on assessment of the carbamates' environmental and potential public health effects is addressed and the major 
contributions are discussed. In addition, this chapter presents the results of some of our laboratory experiments that focus on the evaluation of aminocarb and thiodicarb renal and hepatic toxicity, lymphoid organ damage including the spleen and thymus, and adverse effects on male reproductive organs.

\section{Mode of action and toxicology}

Several key issues on carbamate pesticides such as mechanism of action, and toxicological aspects, including adverse human health effects were recently reported by our group [3]. Briefly, this paper also addresses other topics for a better understanding of toxicological effects, namely risk and exposure assessment, biomonitoring, and analytical methods for the detection of these chemicals on foodstuffs and biological fluids or tissues (e.g. blood, serum, urine, breast milk, hair). International legislation was also mentioned in this report.

Carbamates are esters of N-methyl carbamic acid, known as acetylcholinesterase-inhibiting agents (AChE). As with other pesticides like organophosphates, carbamates inhibit the acetylcholine esterase enzyme which catalyzes the hydrolysis of acetylcholine (Ach), a neuromediator agent, which results in ACh increase at a nerve synapse or neuromuscular junction, thereby increasing stimulation of those nerve endings [4]. Carbamates' cholinesterase-inhibiting effect is reversible compared to organophosphates which is irreversible.

The range of the toxicity of carbamates is variable [5]. Several carbamates have slight $\left(\mathrm{LD}_{50}>\right.$ $200 \mathrm{mg} / \mathrm{kg}$ ) to highly $\left(\mathrm{LD}_{50}<50 \mathrm{mg} / \mathrm{kg}\right.$ ) toxic activity in rodents (Table 1 ). For example thiodicarb (dimethyl $N$, $N^{\prime}$-thiobis (methylimino) carbonyloxy bisethanimido thioate) is a conventional insecticide for controlling cotton bollworm [6]. It is categorized as class II, moderately toxic, by USEPA and World Health Organization (WHO). In addition, several factors including the route, duration, and frequency of exposure, contact with other pollutants, and compromised physiological condition (e.g. hepatic injury) may determine the degree of toxicity [7-8].

Among other pesticides, some carbamates were included in the list of endocrine-disrupting chemicals (EDCs) by WHO [1]. Due to the potential dangerous effects on both wildlife and human health, this issue has received considerable attention within the scope of public health. The potential of EDCs to interfere with the synthesis, secretion, transport, metabolism, and elimination of a wide range of hormones was already established. These hormonally active chemicals may induce a wide range of deleterious health effects such as developmental, behavioral and reproductive deficits. Agonistic and antagonist mechanism was described. Recently, De Coster and van Larebeke [9] presented an overview of relevant chemicals with endocrine disrupting features, including carbamate pesticides such as chlorpropham, carbaryl, benomyl, methiocarb, pirimicarb, and propamocarb. In this well designed review, authors provided different mechanisms such as the activation of the classical $\operatorname{ER} \alpha$ and $\operatorname{Er} \beta$ nuclear receptors, through estrogen associated receptors, and membrane-bound estrogen-receptors, among others. 


\section{Potential public health risks}

A growing body of literature evidences the harmful effects of carbamates and other pesticides on human and environmental health. Carbamates have been analyzed in environmental analysis, food safety, toxicology, and occupational health. Due to the extensive use of carbamates for agricultural and non-agricultural purposes, their residues have been detected in soils, wastewater effluents, surface water and raw drinking water sources, as well as food products, around the world, and have received particular attention because of their toxicity. The control of the levels of the residues of these compounds in the environment and in crops has an outstanding importance. The presence of pesticide residues and/or their degradation products, which sometimes are more toxic than their precursors in the environment and in foodstuffs, calls for the use of very sensitive analytical methods, capable of determining these compounds at concentration levels equal to or lower than the maximum residue levels (MRLs) established by international organizations [10]. Except for occupational exposure or at home application, e.g. home gardens or the handling with domestic animals, people are exposed to pesticides mainly through diet. Human intake due to pesticide residues in food commodities is usually much higher than those related to water consumption and air inhalation. The evaluation of pesticide residues in food is nowadays a priority objective to ensure food quality and safety, as well as to protect consumers against potential health risks [3, 11]. Considering the chronic exposure through food, Jensen and co-workers [12] used the probabilistic approach to estimate the cumulative exposure to organophosphorus and carbamate pesticide residues from the consumption of fruit, vegetables and cereals in the population of Denmark. Despite the limitations and the uncertainties in the calculation of the dietary cumulative intake, the results showed that exposure for children aged up to 6 years were, on average, 2.4 times higher than the exposure for the general population. Tomatoes were the food source that provided about $67 \%$ of the total intake of acetylcholinesterase enzyme-inhibiting pesticides. An outbreak of food borne-illness was reported due to severe methomyl intoxication in Korea [8]. Six elderly people collapsed abruptly after eating 1-2 spoons of boiled rice mixed with bean sprouts and seasoned with soybean sauce. One patient died of cardiac arrest. Symptoms of toxicity presented quickly in the subjects and progressed rapidly, including chest tightness, an unusual sensation in the pit of the stomach, dizziness, ataxia, and finally, collapse. Three patients who drank ethanol with the meal experienced only mild toxic symptoms [8].

The relationships between possible exposure to pesticides and the implications for human health have been the matter of exhaustive and multiple reviews [9, 13-21]. The overall conclusions are that pesticides may induce chronic health complications leading to several diseases. For example neurodevelopmental or behavioral problems, birth defects, asthma, and cancer were documented in children [22].

Due to the relevance of hormones through the life cycle, EDCs may interfere with the developmental processes of humans and wildlife species. The extent of exposure to EDCs may severely affect the most vulnerable life stages including prenatal, early postnatal life, and children. Developmental exposures may induce alterations that, while not evident as birth 
defects, can promote permanent changes that lead to increased incidence of diseases throughout life [1].

Several recent reports indicate a correlation between EDCs and numerous chronic diseases such as cancer, diabetes, developmental deficits, obesity, and reproductive health disorders. For example, the potential influence of several endocrine disruptor pesticides on human health was reviewed by Mnif and colleagues [15]. Among other carbamates, aldicarb was demonstrated to inhibit the activity of 17 beta-estradiol and progesterone; carbendazim induced an increase of estrogen production and aromatase activity, although low estrogen effect was reported for carbaryl.

Deleterious health effects of some carbamates chronic exposure in occupational settings were already described, and environmental and public health impacts also considered [14]. Occupational pesticide exposure associated with cancer incidence is thoroughly discussed elsewhere. Alavanja and Bonner reviewed association between carbamates such as aldicarb and carbaryl with colon cancer and melanoma, respectively [23]. In this review and concerning the U.S. Agricultural Health Study (AHS), specific pesticide exposures ascertained by questionnaire prior to the onset of disease were found to be significantly associated with cutaneous melanoma (eg. for more than 56 days of exposure to carbaryl) [23]. Also positive relations between non-Hodgkin lymphoma and carbamate insecticides, among other pesticide exposures in occupational agricultural sceneries, were also lately reported [21]. The relationship between carbamate pesticides, namely carbaryl, and multiple myeloma occurrence was recently described [24].

The association between occupational exposure to organophosphate and carbamate pesticides and semen quality, as well as reproductive and thyroid hormone profiles of Venezuelan farm workers, was undertaken by Miranda-Contreras and colleagues [19]. These findings confirm the potential impact of occupational exposure to EDCs on male reproductive function. Features like sperm chromatin damage and reduction of semen were documented and adverse reproductive health outcomes were detected. The evidence available today shows that both men and women can experience adverse reproductive effects as a result of chronic exposure to carbamate pesticides.

Occupational pesticides non-intentional poisoning was also reviewed recently and carbamates were one of the main groups of pesticides-related mortalities in Brazil [25]. Multiple routes may be considered (inhalation, dermal, oral), with skin contact being one of most common routes of exposure. Protective measures for pesticides exposure related with dermal route of exposure were recently reviewed [26]. In fact, safe handling through personal protective equipment may reduce absorption of those chemicals. In the Republic of Korea, mortality studies due to organophosphate and carbamate poisoned patients (occupationally linked acute exposures or suicides) were recently reported in which 17 cases, under the age of $56.8 \pm 19.2$ years were found among a total of 146 [7]. Unlike other types of intoxication, there are definite antidotes for carbamates exposure. The mortality of these disease entities could be diminished with sufficient use of atropine, 2-pyridine aldoxime methyl chloride (2-PAM, known as pralidoxime) and vigorous airway management if used from the early stage of their occurrence [7]. 


\section{In vivo studies}

As for other hazardous chemicals, the contribution of laboratory experimental studies is relevant to understand the impact of carbamate pesticides on public health. Extensive research based on animal experiments, particularly mammals, has evidenced the toxicological effects of a wide range of carbamates. Table 1 displays some relevant contributions of predictive toxicology studies carried out in laboratory animals, based on several approaches. Results clearly show that a number of carbamates have led to a broad spectrum of adverse health effects on different tissues, organs, and systems (hepatic, renal, developmental, and reproductive) in a dose dependent manner with obvious implications on functions. In particular, exposure to carbamates during critical periods of life (eg. pregnancy, and fetal development) induces maternal health anomalies and developmental disability. Generally, apart from hepatic toxicity, harmful effects on reproductive health through altered spermatogenesis, and reduced semen quality have become a noticeable concern.

As shown on Table 1 the most characterized compounds are carbaryl and carbofuran. Alterations on brain, liver, and testis accompanied by testosterone level decay were reported after carbaryl exposure. In addition, nephrotoxic, hepatotoxic and intestinal disruption were documented after intoxication with carbofuran.

Recently, the toxicity of two new carbamates, ethyl-4-bromophenyl-carbamate and ethyl-4chlorophenylcarbamate, was characterized [27, 28]. Authors reported low subchronic toxicity to rats as evidenced by low severity and reversibility of the majority of the observed alterations [28]. Still, degenerative changes in liver, binucleated hepatocytes, and focal coagulative necrosis were noted, and increased lesions were related to high dosage. Biochemical parameters, namely plasma enzymes such as gamma-glutamyltransferase, lactate dehydrogenase, and creatinine exhibited a slight increase.

\begin{tabular}{|c|c|c|c|c|c|}
\hline $\begin{array}{l}\text { Carbamate } \\
\text { Pesticide }\end{array}$ & Animal & $\begin{array}{l}\text { Exposure route \& } \\
\text { dosing }\end{array}$ & $\begin{array}{l}\text { Tissue/Organ } \\
\text { /system }\end{array}$ & Results & Reference \\
\hline Aminocarb & Rat & $\begin{array}{l}\text { Orally, 10, } 20 \text { and } 40 \\
\mathrm{mg} / \mathrm{kg} \text { bw for } 14 \\
\text { days }\end{array}$ & $\begin{array}{l}\text { Blood, liver and } \\
\text { kidney }\end{array}$ & $\begin{array}{l}\text { Hemorrhagic focus on hepatic } \\
\text { and renal parenchyma, toxic } \\
\text { effects on lymphoid organs }\end{array}$ & [29] \\
\hline \multirow[b]{2}{*}{ Bendiocarb } & \multirow[b]{2}{*}{ Rabbit } & $\begin{array}{l}\text { Orally } 5 \mathrm{mg} / \mathrm{kg} \text { bw } \\
\text { daily for } 10 \text { and } 30 \\
\text { days }\end{array}$ & Testis & $\begin{array}{l}\text { Decrease of testicular weight, } \\
\text { degenerative changes on } \\
\text { testicular parenchyma, and } \\
\text { Leydig cells }\end{array}$ & [30] \\
\hline & & $\begin{array}{l}\text { Per os daily at a } \\
\text { dose of } 5 \mathrm{mg} / \mathrm{kg} / \mathrm{bw} \text {, } \\
\text { and after day } 11 \\
\text { received the same } \\
\text { dose every } 48 \mathrm{~h} \text {. }\end{array}$ & Liver & $\begin{array}{l}\text { Affects the liver ultrastructure; } \\
\text { regeneration of the damaged } \\
\text { tissue }\end{array}$ & [31] \\
\hline
\end{tabular}




\begin{tabular}{|c|c|c|c|c|c|}
\hline $\begin{array}{l}\text { Carbamate } \\
\text { Pesticide }\end{array}$ & Animal & $\begin{array}{l}\text { Exposure route \& } \\
\text { dosing }\end{array}$ & $\begin{array}{l}\text { Tissue/Organ } \\
\text { /system }\end{array}$ & Results & Reference \\
\hline $\begin{array}{l}\text { Ethyl-4- } \\
\text { bromphenyl- } \\
\text { carbamate and } \\
\text { ethyl-4- } \\
\text { chlorphenyl- } \\
\text { carbamate }\end{array}$ & Rat & $\begin{array}{l}\text { Subchronic oral } \\
\text { toxicities; drinking } \\
\text { water }(12.5,25 \text { and } \\
50 \mathrm{mg} / \mathrm{kg} / \text { day) for } 90 \\
\text { days } \\
5,50,300 \text { and } \\
2000 \mathrm{mg} / \mathrm{kg} \text { single } \\
\text { dose using an } \\
\text { intragastric tube }\end{array}$ & $\begin{array}{l}\text { Many organs } \\
\text { Lung, brain, } \\
\text { cerebellum, } \\
\text { intestine, stomach, } \\
\text { liver, kidney, heart, } \\
\text { and muscle. }\end{array}$ & $\begin{array}{l}\text { Low subchronic toxicity } \\
\text { and reversibility on liver, and } \\
\text { spleen. } \\
\text { Both carbamates are low } \\
\text { hazard; signs of toxicity at the } \\
\text { higher dosages. The maximum } \\
\text { dose of each carbamate did not } \\
\text { cause } \\
\text { clinical manifestations or liver } \\
\text { and skin alterations }\end{array}$ & $\begin{array}{l}{[28]} \\
{[27]}\end{array}$ \\
\hline \multirow{3}{*}{ Carbaryl } & Rat & $\begin{array}{l}\text { Orally Chlorpyrifos, } \\
\text { carbaryl and a } \\
\text { mixture for } 90 \\
\text { consecutive days. } \\
\text { per os }\end{array}$ & Liver, kidney, urine & $\begin{array}{l}\text { No significant } \\
\text { histopathological changes; } \\
\text { mitochondrial enzymes were } \\
\text { affected }\end{array}$ & [32] \\
\hline & Rat & $\begin{array}{l}10,30 \mathrm{mg} / \mathrm{kg} \text { via } \\
\text { intraperitoneal } 35 \\
\text { days of exposure }\end{array}$ & $\begin{array}{l}\text { Blood } \\
\text { testis }\end{array}$ & $\begin{array}{l}\text { Decline in the testosterone } \\
\text { levels; increase in LH and FSH } \\
\text { levels } \\
\text { Decrease in number of germ } \\
\text { cells }\end{array}$ & [33] \\
\hline & Rat & $\begin{array}{l}\text { oral gavage at } 2 \\
\mathrm{ml} / \mathrm{kg} \\
\text { preweaning age to } \\
\text { senescence }\end{array}$ & Brain, plasma, liver & $\begin{array}{l}\text { Dose-related increase at all } \\
\text { ages, with differences across } \\
\text { life span }\end{array}$ & [34] \\
\hline \multirow{3}{*}{ Carbendazim } & Rat & $\begin{array}{l}\text { Orally at } 0,20,100 \\
\text { and } 200 \mathrm{mg} / \mathrm{kg} \text { for } \\
80 \text { days prior to } \\
\text { mating. }\end{array}$ & Testis & $\begin{array}{l}\text { Adverse effects on } \\
\text { spermatogenesis, resulting in } \\
\text { reduced fertility }\end{array}$ & [35] \\
\hline & Mouse & $\begin{array}{l}\text { Mated mice } 0,150, \\
300, \text { and } 600 \\
\mathrm{mg} / \mathrm{kg} / \text { day by } \\
\text { gavage. }\end{array}$ & $\begin{array}{l}\text { Maternal Blood } \\
\text { Fetuses }\end{array}$ & $\begin{array}{l}\text { Dose of } 150 \mathrm{mg} / \mathrm{kg} / \text { day } \\
\text { induced a very slight increase } \\
\text { in postimplantation loss; } \\
\text { maternal and developmental } \\
\text { toxicity at } 300 \text { and } 600 \\
\mathrm{mg} / \mathrm{kg} / \text { day }\end{array}$ & [36] \\
\hline & Rat & $\begin{array}{l}\text { Once daily } \\
\text { p.o. at } 10 \mathrm{ml} / \mathrm{kg} \text { for a } \\
\text { dose of } 200 \mathrm{mg} / \mathrm{kg} / \\
\text { day. }\end{array}$ & Testis & $\begin{array}{l}\text { Tubular dilation, } \\
\text { tubular necrosis, and/or germ } \\
\text { cell degeneration }\end{array}$ & [37] \\
\hline Cartap, carbofuran & Rat & $\begin{array}{l}\text { Each pesticide per se } \\
\text { (50\% LD50); }\end{array}$ & Serum & $\begin{array}{l}\text { Alterations in the serum lipid } \\
\text { profile; marked decrease in }\end{array}$ & [38] \\
\hline
\end{tabular}




\begin{tabular}{|c|c|c|c|c|c|}
\hline $\begin{array}{l}\text { Carbamate } \\
\text { Pesticide }\end{array}$ & Animal & $\begin{array}{l}\text { Exposure route \& } \\
\text { dosing }\end{array}$ & $\begin{array}{l}\text { Tissue/Organ } \\
\text { /system }\end{array}$ & Results & Reference \\
\hline & & $\begin{array}{l}\text { combination of these } \\
\text { two with } 25 \% \text { LD50 } \\
\text { of each during } 1 \\
\text { week } \\
\text { Orally. }\end{array}$ & & $\begin{array}{l}\text { HDL; enhanced effect on levels } \\
\text { of serum lipids in co- } \\
\text { adiministration }\end{array}$ & \\
\hline \multirow{3}{*}{ Carbofuran } & Rat & $\begin{array}{l}4.0 \mathrm{mg} / \mathrm{kg} / \mathrm{bw} \text { for } 7 \\
\text { days or } 2.8 \\
\mathrm{mg} / \mathrm{kg} / \mathrm{bw} \text { for } 30 \\
\text { days daily by Ryle's } \\
\text { tube. }\end{array}$ & Small Intestine & $\begin{array}{l}\text { Intestinal distruption of the } \\
\text { villi, and comet assay showed } \\
\text { disintegration of DNA in } \\
\text { enterocytes of animals exposed } \\
\text { for } 30 \text { days; toxicity may } \\
\text { modulate digestive functions } \\
\text { in intestine }\end{array}$ & [39] \\
\hline & Rat & $\begin{array}{l}\text { Orally } 1 \mathrm{mg} / \mathrm{kg} / \mathrm{bw} \\
\text { dissolved in } \\
\text { sunflower oil daily } \\
\text { for } 28 \text { days }\end{array}$ & $\begin{array}{l}\text { Kidneys } \\
\text { blood }\end{array}$ & $\begin{array}{l}\text { Nephrotoxic effects through } \\
\text { augmented oxidative } \\
\text { stress and attenuated } \\
\text { antioxidant defense system }\end{array}$ & [40] \\
\hline & Rat & $\begin{array}{l}\text { P.o at } 0-5 \mathrm{mg} / \mathrm{kg} / \\
\text { bw for } 5 \text { weeks }\end{array}$ & Liver, bone marrow & $\begin{array}{l}\text { Liver toxicity and clastogenic } \\
\text { effects (micronucleated } \\
\text { polychromatic erythrocytes) }\end{array}$ & [41] \\
\hline Carbosulfan & Rat & $\begin{array}{l}\text { Orally }(0.5,1,2 \text {, and } \\
4 \mathrm{mg} / \mathrm{kg}) \text { during the } \\
\text { embryonic period } \\
(1-15)\end{array}$ & Brain & $\begin{array}{l}\text { High developmental disability } \\
\text { in pups (changes in } \\
\text { sensorimotor functions, and } \\
\text { high anxiety) in pups; growth } \\
\text { rate changes in a dose } \\
\text { dependent manner. }\end{array}$ & [42] \\
\hline \multirow[b]{2}{*}{ Methiocarb } & \multirow[b]{2}{*}{ Rat } & $\begin{array}{l}\text { Orally at doses } 25, \\
10 \text {, and } 2 \mathrm{mg} / \mathrm{kg} / \mathrm{bw} \\
\text { for } 1,5 \text {, and } 28 \text { days }\end{array}$ & $\begin{array}{l}\text { Liver, kidney, brain, } \\
\text { and testis }\end{array}$ & $\begin{array}{l}\text { Possible lipid peroxidation, } \\
\text { disturbances on the GSH levels } \\
\text { in liver, kidney, testis, and } \\
\text { brain }\end{array}$ & [43] \\
\hline & & $\begin{array}{l}25 \mathrm{mg} / \mathrm{kg} / \mathrm{bw} \text { for } 20 \\
\text { days, (i.g.) }\end{array}$ & Liver,and kidney & $\begin{array}{l}\text { Oxidative damage on liver and } \\
\text { kidney, which were partly, } \\
\text { ameliorated by the } \\
\text { pretreatment of vitamin E and } \\
\text { taurine. }\end{array}$ & [44] \\
\hline Methomyl & Mouse & $\begin{array}{l}\text { Orally; } 1 \mathrm{mg} ; 2 \mathrm{mg} \text {, } 3 \\
\mathrm{mg} \text { and } 4 \mathrm{mg} / \mathrm{kg} / \mathrm{bw} \\
\text { for } 30 \text { days and } \\
\text { effective dose of } 4 \\
\mathrm{mg} / \mathrm{kg} / \mathrm{bw} \text { for } 5,10 \text {, } \\
\text { and } 20 \text { days }\end{array}$ & Liver and serum & $\begin{array}{l}\text { Harmful effects on cell } \\
\text { metabolism, cell membrane } \\
\text { permeability, and hepatic } \\
\text { detoxification system }\end{array}$ & [45] \\
\hline
\end{tabular}




\begin{tabular}{|c|c|c|c|c|c|}
\hline $\begin{array}{l}\text { Carbamate } \\
\text { Pesticide }\end{array}$ & Animal & $\begin{array}{l}\text { Exposure route \& } \\
\text { dosing }\end{array}$ & $\begin{array}{l}\text { Tissue/Organ } \\
\text { /system }\end{array}$ & Results & Reference \\
\hline & Rat & $\begin{array}{l}\text { Orally daily for } 65 \\
\text { days at } 2 \text { doses }(0.5 \\
\left.\text { and } 1.0 \mathrm{mg} \mathrm{kg}^{(-1)} \mathrm{bw}\right)\end{array}$ & $\begin{array}{l}\text { Testis, epididymis, } \\
\text { and serum }\end{array}$ & $\begin{array}{l}\text { Decreased the fertility index, } \\
\text { testicular damage, sperm } \\
\text { quality affected }\end{array}$ & [46] \\
\hline Pirimicarb & Mouse & $\begin{array}{l}\text { Oral gavage } 2.14 \text {, } \\
\text { and } 10.7 \mathrm{mg} / \mathrm{kg} / \text { day } \\
\text { pirimicarb, and } \\
\text { dichlorvos plus } \\
\text { pirimicarb daily for } \\
30 \text { consecutive days }\end{array}$ & Liver and serum & $\begin{array}{l}\text { Prominent changes in liver } \\
\text { oxidative markers, as } \\
\text { endogenous metabolites } \\
\text { in serum and liver; PI, either } \\
\text { alone or in combination lead to } \\
\text { changes on liver glucose, fat } \\
\text { and protein metabolism, } \\
\text { energy metabolism and } \\
\text { oxidative balance }\end{array}$ & [47] \\
\hline \multirow[b]{2}{*}{ Thiodicarb } & \multirow[b]{2}{*}{ Rat } & $\begin{array}{l}\text { Orally daily at } 10 \text {, } \\
20 \text {, or } 40 \mathrm{mg} / \mathrm{kg} / \mathrm{bw} \\
\text { during } 30 \text { days }\end{array}$ & $\begin{array}{l}\text { Liver, kidneys, } \\
\text { spleen, testis and } \\
\text { thymus }\end{array}$ & Organ toxicity to high doses & [48] \\
\hline & & $\begin{array}{l}\text { Intraperitoneal, } 2.9 \\
\text { and } 5.8 \mathrm{mg} / \mathrm{kg} \text { daily } \\
\text { for } 28 \text { days }\end{array}$ & $\begin{array}{l}\text { Vital organs, } \\
\text { particularly liver } \\
\text { and heart }\end{array}$ & $\begin{array}{l}\text { Significant increase in AST on } \\
\text { 7th day. No much changes on } \\
\text { the various biochemical } \\
\text { profiles except inhibiting } \\
\text { AChE. No adverse specific } \\
\text { damage to vital organs, mainly } \\
\text { liver and heart }\end{array}$ & [49] \\
\hline
\end{tabular}

Table 1. Laboratory animal findings on main carbamate pesticides effects. Abbreviations: bw-body weight; i.g.intragastrically.

\subsection{Case studies: Effects of thiodicarb and aminocarb on male reproductive system}

As presented in Table 1, the effects of thiodicarb on various biochemical parameters and blood enzymes were investigated in adult male wistar rats following its daily intraperitoneal administration at rates of 2.9 and $5.8 \mathrm{mg} / \mathrm{kg}$ for 28 days [49]. The findings of this research indicated that thiodicarb did not significantly affect or alter the various biochemical profiles except inhibiting AChE following intraperitoneal administration up to 28 days.

The systemic toxic effects of thiodicarb on rats have been well described by our group [48]. Several approaches such as hematological, biochemical, histopathological, and flow cytometry were used in this paper to characterize the subacute effects. Marked systemic organ toxicity was reported including renal and testis degeneration, appreciated cellular loss on thymus, hemorrhagic focus on liver, and disruption within the spleen. T lymphocytes displayed high values. This paper also evidenced some hemorrhage on interstitial tissue of testis.

To complement the above mentioned work, and in order to fully characterize the effects of thiodicarb on the male reproductive system of rats, experiments were conducted under the 
guidelines for ethics on animal experimentation using a similar protocol for epididymis (another reproductive organ). Briefly, three months old rats purchased from Harlan Iberica (Spain) were divided into two groups, and kept under appropriate conditions. Thiodicarb was dissolved in water and was given every day ( $40 \mathrm{mg} / \mathrm{kg}$ body weight) for a period of 30 days. For comparison, animals given water only were used. After one month, animals were anesthetized, and sacrificed for epididymis sampling and further histological analyses. No apparent macroscopic changes were noted in organs of thiodicarb-exposed rats. However the observations at light microcope level evidenced a reduction of sperm mass within the lumen (Figure 1). However no changes were noted on the epithelium lining the ducts.
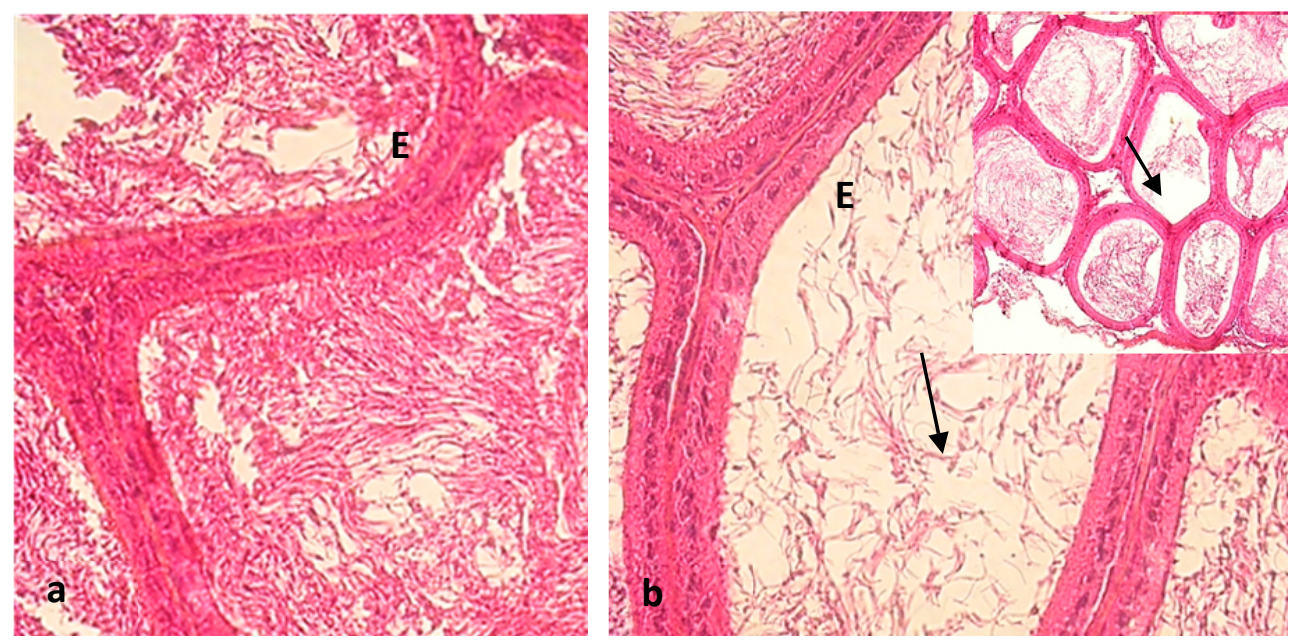

Figure 1. Histological sections of rat epididymis (E) from (a) control; and thiodicarb (40 mg/kg body weight) exposed animals during one month period (b). A considerable decrease on sperm is noted in the lumen (arrow); Inset - a general view displaying a reduction on sperm (arrow); haematoxylin and eosin stain. Original magnification: (a) x200; (b) $\mathrm{x} 200$; inset $\mathrm{x} 40$.

Aminocarb (4-dimethylamino-3-methy-N-carbamate) is a phenylsubstituted methylcarbamate pesticide broadly used to control the growth of insect pests such as Lepidoptera and Coleoptera species affecting agriculture and storage of legumes, fruits, and grains. The toxicity of this carbamate on rats was thoroughly characterized through histological, hematological, and biochemical approaches as shown on Table 1. The results of this study evidenced multiorgan damage and the extension of lesions were dose-dependent. Studies on progress using a similar experimental dosing procedure (30, and $40 \mathrm{mg} / \mathrm{kg}$ body weight, respectively) were conducted in male rats aiming to evaluate the effects of aminocarb on testis and epididymis using histological assays. The results clearly show harmfull effects on both testis and epididymis (Figures 2 and 3). Epidydimis revealed a reduction of sperm compared to control. The testis presented some degenerative changes such as vacuolation, germ cell loss with obvious decrease of seminiferous epithelium, and release of immature germ cells into the lumen. 

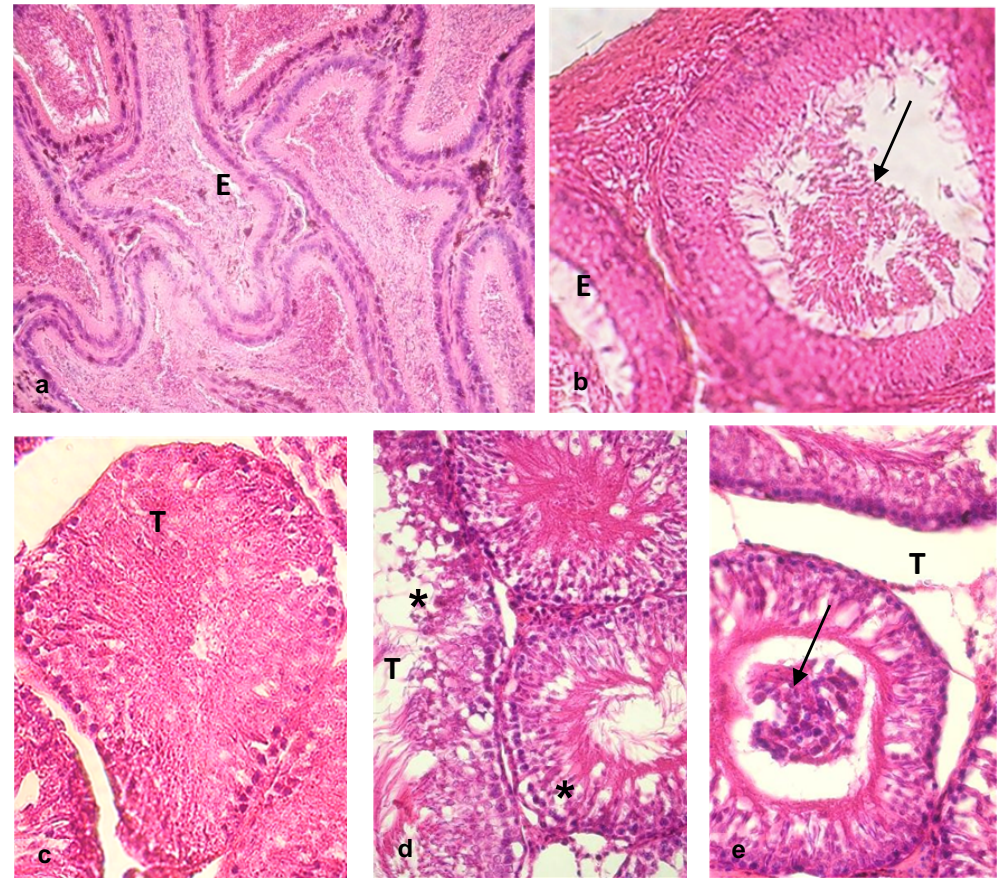

Figure 2. Epididymis (E) of (a) control and aminocarb-dosed rats $(20 \mathrm{mg} / \mathrm{kg}$ ) for 14 days (b) displaying a decrease on sperm (arrow); testis (T) from control (c) and pesticide exposed rat (d-e) evidencing strong vacuolation $\left({ }^{*}\right)$, and immature germ cells (arrow); haematoxylin and eosin stain. Original magnification: (a,) x100; (b) x200; (c-e) x200.

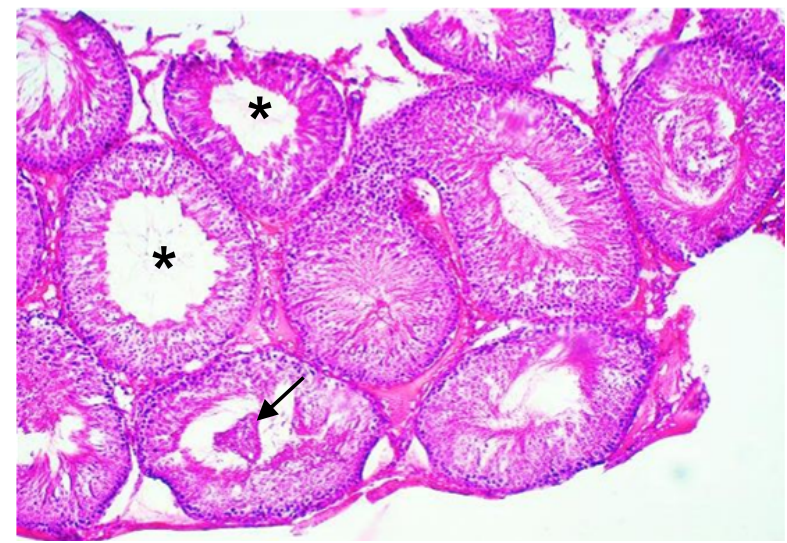

Figure 3. Representative histological section of testis from aminocarb-exposed rat $(40 \mathrm{mg} / \mathrm{kg} / \mathrm{body}$ weight $)$ during 14 days. Immature germ cells (arrow) within the lumen of seminiferous tubules; some tubules $\left(^{*}\right)$ denoted a decrease on germ cell layers; haematoxylin-eosin stain. Original magnification: x100. 
Overall taken together, the results mentioned above clearly evidence the deleterious effects of both carbamates (thiodicarb and aminocarb) on male organs namely testis and epididymis. In fact disrupted spermatogenesis, and subsequent changes in epididymis ducts may compromise the reproductive potential. These findings are consistent with the results from studies on other carbamates reported on Table 1.

\section{Conclusion}

Although efforts have been made globally and a significant progress was accomplished, the impact of carbamates (mainly of those that exhibit endocrine disruptor behavior) on human and environmental health still remains a public health problem and a challenge.

Insights from endocrine disruptor research in animals have a huge impact on current practice in toxicological evaluation. The effects of exposures should be studied in adulthood but also, and particularly, in fetal development, perinatal life, childhood and puberty.

Continuous efforts to undertake multidisciplinary research based on in vitro technologies and in vivo toxicological studies, coupled to the epidemiological studies of exposure in humans are mandatory in order to improve our knowledge on the underlying mechanisms and health consequences. Also, protection programs, including educational ones, on the appropriate use of pesticides to minimize population exposures as well as preventive health monitoring are needed principally in developing countries.

\section{Acknowledgements}

The present work was financed by FEDER Funds through the Programa Operacional Factores de Competitividade - COMPETE, and National Funds through FCT - Fundação para a Ciência e Tecnologia, under the projetc CICECO-FCOMP-01-0124-FEDER-037271 (Ref. FCT PEstC/CTM/LA0011/2013). Authors are greatly indebted to the Serviço de Patologia Clínica, Centro Hospitalar Baixo Vouga, EPE, Aveiro, Portugal (Director: Dr. Elmano Ramalheira). HoribaABX, SAS, (Portugal), and Siemens Healthcare Diagnostics (Portugal) are also acknowledged. Authors are grateful to Tânia Fernandes.

\section{Author details}

Elsa Dias ${ }^{1,2}$, Fernando Garcia e Costa ${ }^{3}$, Simone Morais $^{4}$ and Maria de Lourdes Pereira ${ }^{1 *}$

*Address all correspondence to: mlourdespereira@ua.pt

1 Departamento de Biologia \& CICECO, Universidade de Aveiro, Aveiro, Portugal 
2 Serviço de Patologia Clínica, Centro Hospitalar Baixo Vouga, EPE, Aveiro, Portugal

3 Departamento de Morfologia e Função, CIISA, Faculdade de Medicina Veterinária, Universidade de Lisboa, Lisboa, Portugal

4 REQUIMTE, Instituto Superior de Engenharia do Porto, Porto, Portugal

\section{References}

[1] World Health Organization (WHO). State of the Science of Endocrine Disrupting Chemicals 2012. United Nations Environment Programme and the World Health Organization, 2013 Geneva.

[2] United States Environmental Protection Agency (US EPA). Water Quality Standards; Establishment of numeric criteria for priority toxic pollutants; States'compliances. Federal Register 1992; 57(246): 60848 (57FR 60848).

[3] Morais S, Dias E and Pereira ML. Carbamates: human exposure and health effects. In: Jokanović M. and Cheyenne WY. (eds.) The Impact of Pesticides. Academy Press 2012. p21-38.

[4] Jokanovic M. Medical treatment of acute poisoning with organophosphorus and carbamate pesticides, Toxicology Letters 2009; 190: 107-115.

[5] International Programme on Chemical Safety (IPCS, 1986), Environmental Health Criteria 64, Carbamate Pesticides: a General Introduction, World Health Organization, Geneva, http://www.inchem.org/documents/ehc/ehc/ehc64.htm\#subsectionnumber:1.1.7.

[6] Saber M, Parsaeyan E, Vojoudi S, Bagheri M, Mehrvar A and Kamita SG. Acute toxicity and sublethal effects of methoxyfenozide and thiodicarb on survival, development and reproduction of Helicoverpa armigera (Lepidoptera: Noctuidae). Crop Protection 2013; 43: 14-17.

[7] Kim KH, Kwon IH, Lee JY, Yeo WH, Park HY, Park KH, Cho J, Kim H, Kim GB, Park DH, Yoon YS and Kim YW. Clinical significance of national patients sample analysis: factors affecting mortality and length of stay of organophosphate and carbamate poisoned patients. Healthcare Informatics Research 2013; 19(4): 278-285.

[8] Gil HW, Jeong MH, Park JS, Choi HW, Kim SY and Hong SY. An Outbreak of Food Borne Illness Due to Methomyl Pesticide Intoxication in Korea. Journal Korean of Medical Science 2013; 28: 1677-1681.

[9] De Coster S and Larebeke N. Endocrine-disrupting chemicals: associated disorders and mechanisms of action. Journal of Environmental and Public Health 2012, doi: 10.1155/2012/713696 52 pages. 
[10] Crespo-Corral E, Santos-Delgado MJ, Polo-Diez LM and Soria AC. Determination of carbamate, phenylurea and phenoxy acid herbicide residues by gas chromatography after potassium ter-butoxide/dimethyl sulphoxide/ethyl iodide derivatization reaction. Journal of Chromatography A 2008; 1209: 22-28.

[11] Sagratini G, Mañes J, Giardiná D, Damiani P and Picó Y. Analysis of carbamate and phenylurea pesticide residues in fruit juices by solid-phase microextraction and liquid chromatography-mass spectrometry. Journal of Chromatography A 2007; 1147: 135-143.

[12] Jensen BH, Petersen A and Christensen T. Probabilistic assessment of the cumulative dietary acute exposure of the population of Denmark to organophosphorus and carbamate pesticides. Food Additives and Contaminants 2009; 26(7): 1038-1048.

[13] George J and Shukla Y. Pesticides and cancer: insights into toxicoproteomic-based findings. Journal of Proteomics 2011; 74(12): 2713-2722.

[14] Imran H. and Dilshad KA. Adverse Health Effects of Pesticide Exposure in Agricultural and Industrial Workers of Developing Country. In: Stoytcheva M (ed.), Pesticides-The Impacts of Pesticides Exposure, InTech; 2011. p155-178.

[15] Mnif W, Hassine AIH, Bouaziz A, Bartegi A, Thomas O and Roig B. Effect of endocrine disruptor pesticides: a review. International Journal of Environmental Research and Public Health 2011; 8: 2265-2303.

[16] Watts M. Human health impacts of exposure to pesticides. $2012 \mathrm{http}: / /$ awsassets.wwf.org.au/downloads/pr_attachment_human_health_impacts_of_exposure_to_pesticides_20mar13.pdf (assessed on 25 july 2014).

[17] Corsini E, Sokooti M, Galli CL, Moretto A and Colosio C. Pesticide induced immunotoxicity in humans: a comprehensive review of the existing evidence. Toxicology 2013; 307: 123- 135.

[18] Hernández AF, Parrón T, Tsatsakis AM, Requena M, Alarcón R and López-Guarnido O. Toxic effects of pesticide mixtures at a molecular level: their relevance to human health. Toxicology 2013; 307: 136-145.

[19] Miranda-Contreras L, Gómez-Pérez R, Rojas G, Cruz I, Berrueta L, Salmen S, Colmenares M, Barreto S, Balza A, Zavala L, Morales Y, Molina Y, Valeri L, Contreras CA and Osuna JA. Occupational exposure to organophosphate and carbamate pesticides affects sperm chromatin integrity and reproductive hormone levels among venezuelan farm workers. Journal of Occupational Health 2013; 55: 195-203.

[20] Sugeng AJ, Beamer PI, Lutz EA and Rosales CB. Hazard-ranking of agricultural pesticides for chronic health effects in Yuma County, Arizona. Science of the Total Environment 2013; 463-464: 35-41.

[21] Schinasi L and Leon ME. Non-Hodgkin lymphoma and occupational exposure to agricultural pesticide chemical groups and active ingredients: a systematic review and 
meta-analysis. International Journal of Environmental Research and Public Health 2014; 11: 4449-4527.

[22] Roberts JR, Karr CJ and Council on Environmental Health. Pesticide exposure in children. Pediatrics 2012; 130(6): e1765-e1788.

[23] Alavanja MC and Bonner MR. Occupational Pesticide Exposures and cancer risk: a review. Journal of Toxicology and Environmental Health Part B 2012; 15(4): 238-263.

[24] Kachuri L, Demers PA, Blair A, Spinelli JJ, Pahwa M, McLaughlin JR, Pahwa P, A Dosman JA and Harris SA. Multiple pesticide exposures and the risk of multiple myeloma in Canadian men. International Journal of Cancer 2013; 133: 1846-1858.

[25] Santana VS, Moura MCP, Ferreira e Nogueira F. Occupational pesticide poisoning, 2000-2009, Brazil. Revista de Saúde Pública 2013; 47(3): 1-8.

[26] MacFarlane E, Carey R, Keegel T, El-Zaemay S and Fritschi L. Dermal Exposure Associated with Occupational End Use of Pesticides and the Role of Protective Measures. Safety and Health at Work 2013; 4(3): 136-141.

[27] Prado-Ochoa MG, Gutiérrez-Amezquita RA, Abrego-Reyes VH, Velázquez-Sánchez A, Muñoz-Guzmán MA, Ramírez-Noguera P, Angeles E. and Alba-Hurtado F. Assessment of Acute Oral and Dermal Toxicity of 2 Ethyl-Carbamates with Activity against Rhipicephalus microplus in Rats. BioMedical Research International 2014a, in press. doi: 10.1155/2014/956456.

[28] Prado-Ochoa MG, Abrego-Reyes VH, Velázquez-Sánchez AM, Muñoz-Guzmán MA, Ramírez-Noguera P, Angeles E and Alba-Hurtado F. Subchronic toxicity study in rats of two new ethyl-carbamates with ixodicidal activity. BioMedical Research International 2014b, in press. doi: 10.1155/2014/467105.

[29] Dias E, Morais S, Ramalheira E and Pereira ML. Characterization of the toxicological effects of aminocarb on rats: hematological, biochemical and histological analyses. Journal of Toxicology and Environmental Health A. 2014; 77: 849-855.

[30] Almasiova V, Holovska K, Tarabova L, Cigankova V, Lukacinova A and Nistiar F. Structural and ultrastructural study of rabbit testes exposed to carbamate insecticide. Journal of Environmental Science Health 2012; 47: 1319-1328.

[31] Holovska K. Almasiova V and Cigankova V. Ultrastructural changes in the rabbit liver induced by carbamate insecticide bendiocarb. Journal of Environmental Science and Health 2014; 49: 616-623.

[32] Wang HP, Liang YJ, Zhang Q, Long DX, Li W, Li L, Yang L, Yan XZ and Wu YJ. Changes in metabolic profiles of urine from rats following chronic exposure to anticholinesterase pesticides. Pesticide Biochemistry and Physiology 2011; 101: 232-239.

[33] Fattahi E, Jorsaraei SGA and Gardane M. The effect of carbaryl on the pituitary-gonad axis in male rats. Iranian Journal of Reproductive Medecine 2012; 10(5): 419-424. 
[34] Moser VS, Katherine LM, Phillips PM and Lowit AB. Time-course, dose-response, and age comparative sensitivity of N-Methyl carbamates in rats. Toxicological Science 2010; 114: 113-123.

[35] Yu G, Guo Q, Xie L, Liu Y and Wang X. Effects of subchronic exposure to carbendazim on spermatogenesis and fertility in male rats. Toxicology and Industrial Health 2009; 25: 41-47.

[36] Farag A, Ebrahim H, ElMazoudy R, and Kadous E. Developmental toxicity of fungicide carbendazim in female mice. Birth Defects Research 2011; 92:122-130.

[37] Moffit JS, Her LS, Mineo AM, Knight BL, and Phillips JA, and Thibodeau MS. Assessment of inhibin $B$ as a biomarker of testicular injury following administration of carbendazim, cetrorelix, or 1,2-dibromo-3-chloropropane in wistar han rats. Birth Defects Research Part B 2013; 98:17-28.

[38] Rai DK, Rai PK, Gupta A, Watal G, and Sharma B. Cartap and carbofuran induced alterations in serum lipid profile of wistar rats. Indian Journal of Clinical Biochemistry 2009: 24(2): 198-201.

[39] Gera N and Kiran R, Mahmood A. Subacute effects of carbofuran on enzyme functions in rat small intestine. Toxicology Mechanisms and Methods 2009; 19:141-147.

[40] Kaur B, Khera A, and Sandhir R. Attenuation of cellular antioxidant defense mechanisms in kidney of rats intoxicated with carbofuran. Journal of Biochemistry and Molecular Toxicology 2012; 26(10): 393-398.

[41] Gbadegesin MA, Owumi SE, Akinseye V and Odunola OA. Evaluation of hepatotoxicity and clastogenicity of carbofuran in male Wistar rats. Food and Chemical Toxicology 2014; 65:115-119.

[42] Banji D, Banji OJ, Ragini M and Annamalai AR. Carbosulfan exposure during embryonic period can cause developmental disability in rats. Environmental Toxicology and Pharmacology 2014; 38: 230-238.

[43] Ozden S. and Alpertunga B. Effects of methiocarb on lipid peroxidation and glutathione level in rat tissues. Drug and Chemical Toxicology 2010; 33: 50-54.

[44] Ozden S, Catalgol B, Gezginci-Oktayoglu S, Karatug A, Bolkent S and Alpertunga B. Acute effects of methiocarb on oxidative damage and the protective effects of vitamin $\mathrm{E}$ and taurine in the liver and kidney of Wistar rats. Toxicology and Industrial Health 2012; 29(1): 60-71.

[45] Manawadi S and Kaliwal BB. Methomyl induced alteration in mice hepatic-oxidative Status. International Journal of Biotechnology Applications 2010; 2(2): 11-19.

[46] Shalaby MA, El Zorba HY and Ziada RM. Reproductive toxicity of methomyl insecticide in male rats and protective effect of folic acid. Food and Chemical Toxicology 2010; 48: 3221-3226. 
[47] Wang P, Wang HP, Xu MY, Liang YJ, Sun YJ, Yang L, Li L, Li W and Wu YJ. Combined subchronic toxicity of dichlorvos with malathion or pirimicarb in mice liver and serum: A metabonomic study. Food and Chemical Toxicology 2014; 70: 222-230.

[48] Dias E, Gomes M, Domingues C, Ramalheira E, Morais S, and Pereira ML. Subacute effect of the thiodicarb pesticide on target organs of male wistar rats: biochemical, histological, and flow cytometry studies. Journal of Toxicology and Environmental Health A. 2013; 76(9): 533-539.

[49] Satpal, Jain SK and Punia JS. Studies on Biochemical Changes in subacute thiodicarb toxicity in rats. Toxicology International 2010; 17: 30-32. 